\title{
PENGARUH PENGAMBILAN KEPUTUSAN KONSUMEN DALAM MEMBELI PRODUK BUSANA MUSLIMAH DI KOTA PEKANBARU (STUDI KASUS INDUSTRI FASHION BUSANA MUSLIMAH DI KOTA PEKANBARU )
}

\author{
Identiti $^{1}$, Nanda Suryadi ${ }^{2}$, Rimet ${ }^{3}$, Virna Museliza ${ }^{4}$ \\ Universitas Islam Negeri Sultan Syarif Kasim Riau \\ iden2306@gmail.com
}

\begin{abstract}
The purpose of this study is to see the effect of consumer decision -making in buying Muslimah clothing products in the city of Pekanbaru so that consumers are not wrong in making decisions in buying Muslimah clothing products. The population of this study is all 100 people obtained using the calculation of the slovin formula. Sampling using stratified random sampling method. Data collection techniques used questionnaires with Likert scale. Data analysis technique with path analysis using the help of SEM Smart PLs software. The results of this study show that the Sharia Lifestyle has a positive and significant effect on the Purchase Decision, Price has a positive and significant effect on the purchase decision, Products have a positive and significant effect on the purchase decision.
\end{abstract}

Keywords: Syariah lifestyle, Price, Product, Purchase Decision

\begin{abstract}
ABSTRAK
Tujuan penelitian ini adalah untuk melihat pengaruh pengambilan keputusan konsumen dalam membeli produk busana muslimah di kota Pekanbaru agar para konsumen tidak salah mengambil keputusan dalam membeli produk busana muslimah.Populasi dari penelitian ini adalah seluruh Pelanggan wanita toko busana muslimah di kota Pekanbaru. Sampel penelitian ini sebanyak 100 orang yang diperoleh menggunakan perhitungan rumus slovin.Pengambilan sampel menggunakan metode stratified random sampling. Teknik pengumpulan data menggunakan kuisioner dengan skala likert. Teknik analisis data dengan path analysis menggunakan bantuan softwere SEM Smart PLs. Hasil penelitian ini menunjukkan bahwa Gaya Hidup Syariah berpengaruh positif dan signifikan terhadap Keputusan Pembelian, Harga Berpengaruh positif dan signifikan terhadap keputusan pembelian, Produk Berpengaruh positif dan signifikan terhadap keputusan pembelian
\end{abstract}

Kata Kunci : Gaya Hidup Syariah, Harga, Produk, Keputusan Pembelian

\section{PENDAHULUAN}

Perkembangan industri busana muslimah di Indonesia dapat berkembang optimis karena didukung dengan faktor- faktor terkait perkembangan bisnis busana dimana terdapat 
bahan baku yang melimpah serta kondisi atau keadaan iklim bisnis busana di Indonesia yang kondusif.

Dewasa ini busana muslimah terus melakukan transformasi dari gaya konservatif menjadi lebih kontemporer yang berjiwa muda. Busana muslimah yang lebih hidup dan berwarna di Indonesia menunjukkan bahwa budaya Islam di Indonesia terbuka pada modernisasi, toleran, menerima perbedaan, dan cinta keragaman. Pertumbuhan industri busana muslimah dapat menggambarkan karakteristik dan budaya masyarakat Islam Indonesia yang kreatif di mata dunia.

Tujuan perdagangan dalam Islam adalah untuk terciptanya kemaslahatan diantara umat menusia dan tolong menolong. Dengan adanya pedagangan dapat merealisasikan kemanfaatan sebesar mungkin bagi kaum muslimin dan menjauhkan mereka dari kemudharatan yang terjadi.

Pada tahun 2016, sektor industri tekstil menyumbangkan persentase sebesar $18 \%$ dari total PDB Indonesia. Dengan proporsi hasil produksi dari industri busana muslimah adalah sebesar 30,8\% dari total hasil Industri tekstil pada tahun tersebut (Data : Badan Pusat Statistik 2016).

Data Produk Domestik Bruto Atas Dasar Harga Berlaku Tahun 2011 - 2016(Dalam Milyar

\begin{tabular}{lllllll}
\multicolumn{7}{c}{ Rupiah) } \\
& $\mathbf{2}$ & $\mathbf{2}$ & $\mathbf{2}$ & $\mathbf{2 0}$ & $\mathbf{2 0}$ & $\mathbf{2 0}$ \\
& $\mathbf{0 1 1}$ & $\mathbf{0 1 2}$ & $\mathbf{0 1 3}$ & $\mathbf{1 4}$ & $\mathbf{1 5}$ & $\mathbf{1 6}$ \\
\hline \multicolumn{1}{c}{ PD } & 7. & 8. & 9. & 10. & 11. & 12. \\
$\mathbf{B}$ & 831,726 & 615,705 & 546,134 & 560,705 & 531,717 & 406,854 \\
\hline In & 1 & 1 & 1 & 13 & 13 & 14 \\
dustri & 08,192 & 16,558 & 29,912 & 9,032 & 9,394 & 0,849 \\
$\begin{array}{l}\text { Tekstil dan } \\
\text { Pakaian }\end{array}$ & & & & & & \\
Jadi & & & & & & \\
\end{tabular}

\begin{tabular}{lllllll}
\hline In & 2 & 3 & 3 & 38. & 40. & 43. \\
dustri & 7,048 & $0.687,87$ & $5.076,23$ & 928,96 & 424,26 & 663,19
\end{tabular}

Busana

Muslim

\begin{tabular}{lllllll}
\hline Pe & 2 & 2 & 2 & 27. & 28, & 30, \\
rsentase & $4,9 \%$ & $6,3 \%$ & $6,9 \%$ & $9 \%$ & $9 \%$ & $9 \%$
\end{tabular}

Sumber : Statistik Ekonomi dan Keuangan Indonesia - Bank Indonesia 
Merdeka.com menyatakan bahwa Industri busana muslimah menjadi penyumbang terbesar dari pertumbuhan industri kecil dan menengah pada sektor tekstil dan pakaian jadi di Indonesia. Pernyataan ini juga didukung berdasarkan data yang ditunjukkan pada tabel 1.1, bahwa volume produksi busana muslimah menguasai lebih dari 30 persen produksi tekstil dan pakaian jadi di Indonesia serta menunjukkan bahwa terdapat pertumbuhan yang pesat pada sektor industri busana muslimah di Indonesia sejak tahun 2011 hingga tahun 2016 dengan tingkat pertumbuhan mencapai lebih dari 50 persen. Hal ini menunjukkan minat konsumen terhadap produk busana muslimah ini semakin bertambah dan potensi yang dapat dikembangkan oleh sektor usaha ini juga semakin besar.

Target pasar industri Fesyen Muslim di Indonesia sangatlah besar karena saat ini kesadaran perempuan muslim untuk menutup aurat sudah tinggi sehingga produk fesyen muslim selalu dicari. Sebagai Kota Madani,Pekanbaru merupakan ibu kotadan kota terbesar di Provinsi Riau. Kota Pekanbaru merupakan salah satu sentra ekonomi terbesar di Pulau Sumatera dengan jumlah penduduk 954,373 jiwa dengan luas $632,26 \mathrm{~km}^{2}$ dan mayoritas penduduknya 84,74\% beragama Islam.

Yasinta (2018 ).mengatakan secara parsial Gaya hidup syariah dan Harga berpengaruh terhadap keputusan pembelian produk kecantikan muslimah. Firti (2019) mengatakan Gaya hidup syariah berpengaruh terhadap keputusan pembelian konsumen.

Berdasarkan uraian diatas penulis tertarik inginmelakukanpenelitiandanmenyusunnya dalamsebuah penelitian dengan judul PENGARUH PENGAMBILAN KEPUTUSAN KONSUMEN DALAM MEMBELI PRODUK BUSANA MUSLIMAH DI KOTA PEKANBARU (STUDI KASUS INDUSTRI FASHION BUSANA MUSLIMAH DI KOTA PEKANBARU )

\section{Tujuan Penelitian}

Berdasarkan latar belakang masalah,rumusan masalah maka tujuan penelitian ini adalah sebagai berikut :

1. Untuk Menganalisis Pengaruh Gaya Hidup Syariah terhadap Pengambilan Keputusan Konsumen dalam membeli produk busana muslimah

2. Untuk Menganalisis Pengaruh Harga terhadap Pengambilan Keputusan Konsumen dalam membeli produk busana muslimah

3. Untuk Menganalisis Pengaruh Produk terhadap Pengambilan Keputusan Konsumen dalam membeli produk busana muslimah 


\section{Manfaat Penelitian}

a. Teoritis

Penelitian ini diharapkan dapat memberikan sumbangsih yang berarti, dapat menambah khasanah keilmuan Pendidikan dan sumbangan pemikiran dengan harapan dapat dijadikan bahan studi banding oleh peneliti lainnya.

b. Praktis

1) Bagi Pemerintah dan lembaga terkait dapat dijadikan sebagai bahan pertimbangan dan pengembangan dalam meningkatkan Regulasi Penjualan Busana Muslimah;

2) Bagi Masyarakat dapat menjadi Referensi dalam pemilihan Baju Muslimah yang ada di Pekanbaru

3) Bagi penulis untuk menambah pengalaman, pengetahuan dan bahan masukan dalam pemahaman dan dapat mengaplikasikan ilmu yang didapat selama masa perkuliahan.

\section{TINJAUAN LITERATUR}

\section{Pengertian Gaya Hidup Syariah}

Bahwa konsepsyariahsebagaigayahidup merupakan pola hidup seseorang yang dinyatakan dalam kegiatan atau aktivitas yang halal, minat dan pendapatnya dalam membelanjakan uangnya untuk konsumsi sehari-hari dan kesenangan lainnya secara halal dan bagaimana mengalokasikan waktu secara halal juga.

\section{Indikator Gaya Hidup Syariah}

Gaya hidup adalah pola hidup seseorang di dunia yang terungkap pada aktifitas, minat dan opininya indikator dari gaya hidup yaitusilvia (2009) dalam (Dicky Hamda,2018)

a. Aktivitas

Aktivitas adalah sebuah kegiatan untuk mencapai kesenangan hidup, sebagian besar perhatiannya ditujukan kepada lingkungan diluar rumah, cenderung memilih-milih teman, ingin menjadi pusat perhatian sehingga mereka tidak segan-segan membeli barang mahal.

b. Minat

Minat adalah gaya hidup yang menjadikan kenikmatan sebagai tujuan aktivitas apapun yang dilakukan hanya demi mencapai kenikmatan dan kesenangan hidup

c. Opini 
Opini adalah pendapat atau masukan yang diterima sebagai bahan pertimbangan untuk kemajuan dan meningkatkan mutu kualitas gaya hidup seseorang. Saat ini konsumen hidu/p dengan berbagai kebutuhan yang bervariasi dimana perusahaan harus memenuhi kebutuhan konsumen dengan menciptakan berbagai produk barang dan jasa yang diperlukan oleh konsumen

\section{Faktor-Faktor yang mempengaruhi Gaya hidup Syariah}

Ada pun Faktor yang mempengaruhi gaya hidup : silvia (2009) dalam (Dicky Hamda,2018)

a. Faktor Internal

1. Sikap. Sikap adalah suatu keadaan jiwa dan keadaan pikir yang dipersiapkan untuk memberikan tanggapan terhadap suatu objek dan mempengaruhi secara langsung pada perilaku. Keadaan jiwa tersebut sangat dipengaruhi oleh tradisi, kebiasaan, kebudayaan dan lingkungan sosial.

2. Pengalaman dan Pengamatan. Pengalaman dapat mempengaruhi pengamatan sosial dalam tingkah laku, pengalaman dapat diperoleh dari semua tindakannya dimasa lalu dan dapat dipelajari, melalui belajar orang akan dapat memperoleh pengalaman.

3. Kepribadian. Kepribadian adalah gabungan antara karakteristik individu dan cara berperilaku yang membedakan perilaku dari setiap individu.52 Adapun

b. Faktor eksternal dijelaskan oleh Nugraheni sebagai berikut:

1. Kelompok Referensi. Kelompok referensi yaitu sekelompok orang yang memberikan pengaruh langsung atau tidak langsung terhadap sikap dan perilaku seseorang

2. Keluarga. Keluarga memegang peranan terbesar dan terlama dalam pembentukan sikap dan perilaku individu. Hal ini karena pola asuh orang tua akan membentuk kebiasaan anak yang secara tidak langsung mempengaruhi pola hidupnya. c. Kebudayaan. Kebudayaan yang meliputi pengetahuan, kepercayaan, kesenian, moral, hukum, adat istiadat, dan kebiasaan-kebiasaan yang diperoleh individu sebagai anggota masyarakat. Kebudayaan terdiri dari sesuatu yang dipelajari dari pola perilaku yang normatif, meliputi ciri-ciri pola pikir, merasakan dan bertindak.

\section{Pengertian Harga}

Pengertian harga menurut Michael J.Etzel (2015) adalah nilai yang disebutkan dalam mata uang atau medium moneter lainnya sebagai alat tukar namun di dalam ilmu ekonomi pengertian harga mempunyai hubungan dengan pengertian nilai dan kegunaan. Nilai adalah ukuran jumlah yang diberikan oleh suatu produk apabila produk itu ditukarkan 
dengan produk lain. Sedangkan kegunaan adalah atribut dari sebuah item yang memberikan tingkat kepuasan tertentu pada konsumen.

\section{Indikator harga}

Menurut (Stanton, 2012) menyebutkan indikator harga antara lain :

1. Keterjangkauan hargaYaitu penetapan harga yang dilakukan oleh perusahaan sesuai dengan kemampuan daya beli konsumen. Konsumen dapat menjangkau harga yang telah ditetapkan oleh perusahaan.

2. Kesesuaian harga dengan kualitas produk. Yaitu penetapan harga yang dilakukan perusahaan yang disesuaikan dengan kualitas produk yang dapat diperoleh konsumen.

3. Daya saing hargaYaitu penawaran harga yang dilakukan oleh perusahaan berbeda dan bersaing dengan yang diberikan oleh perusahaan lain pada jenis produk yang sama.

4. Kesesuaian harga dengan manfaat Yaitu penetapan harga yang dilakukan oleh perusahaan yang sesuai dengan manfaat yang dapat diperoleh konsumen dari produk yang dikonsumsi.

\section{Faktor-Faktor yang mempengaruhi penetapan harga (Stanton, 2012)}

a. Faktor yang secara langsung adalah harga bahan baku, biaya produksi, biaya pemasaran, peraturan pemerintah, dan faktor lainnya.

b. Faktor yang tidak langsung namun erat dengan penetapan harga adalah antara lain yaitu harga produk sejenis yang djual oleh para pesaing, pengaruh harga terhadap hubungan antara produk subtitusi dan produk komplementer, serta potongan untuk para penyalur dan konsumen

\section{Pengertian Produk}

Menurut Hermawan Kertajaya, produk adalah segala sesuatu yang dapat ditawarkan kepada pasar untuk mendapatkan perharian dimilik digunakan atau dikonsumsi yang meliputi barang secara fisik, jasa, kepribadian, tempat, organisasi dan gagasan atau sebuah pikiran.

\section{Indikator Produk}

Menurut Kotler dan Keller (2011:82) indikator variasi produk adalah sebagai berikut:

1. Ukuran Ukuran didefinisikan sebagai bentuk, model dan struktur fisik dari suatu prodok yang dilihat dengan nyata dan dapat diukur.

2. Harga Harga adalah sejumlah uang yang mempunyai nilai tukar untuk memperoleh keuntungan dari memiliki atau menggunkan sebuah produk atau jasa.

3. Tampilan Tampilan adalah segala sesuatu yang ditampilkan oleh produk tersebut, tampilan merupakan daya tarik produk yang dilihat secara langsung oleh konsumen. Tampilan dalam sebuah kemasan produk dapat diartikan sebagai sesuatu yang terlihat 
dengan mata dan bersifat menarik konsumen untuk melakukan keputusan pembelian

4. Ketersedian produk Ketersedian produk yaitu banyaknya macam barang yang tersedia didalam toko membuat para konsumen semakin tertarik untuk melakukan keputusan pembelian dalam toko tersebut telah habis dirak maka dapat diisi lagi.

\section{Keputusan Pembelian}

Menurut Kotler dan Armstrong (2014:158), "Consumer buyer behavior refers to the buying behavior of final consumers - individuals and households that buy goods and services for personal consumption", pengertian tersebut dapa diartikan bahwa perilaku keputusan pembelian mengacu pada perilaku pembelian akhir dari konsumen, baik individual, maupun rumah tangga yang membeli barang dan jasa untuk konsumsi pribadi.

\section{Indikator Keputusan Pembelian}

Menurut Kotler $(2014 ; 70)$ ada empat indikator keputusan pembelian, yaitu :

1. Kemantapan pada sebuah produk.

2. Kebiasaan dalam membeli produk.

3. Memberikan rekomendasi kepada orang lain.

4. Melakukan pembelian ulang.

\section{Kerangka Konseptual}

Adapun Kerangka Konseptual dari penelitian ini adalah sebagai berikut :

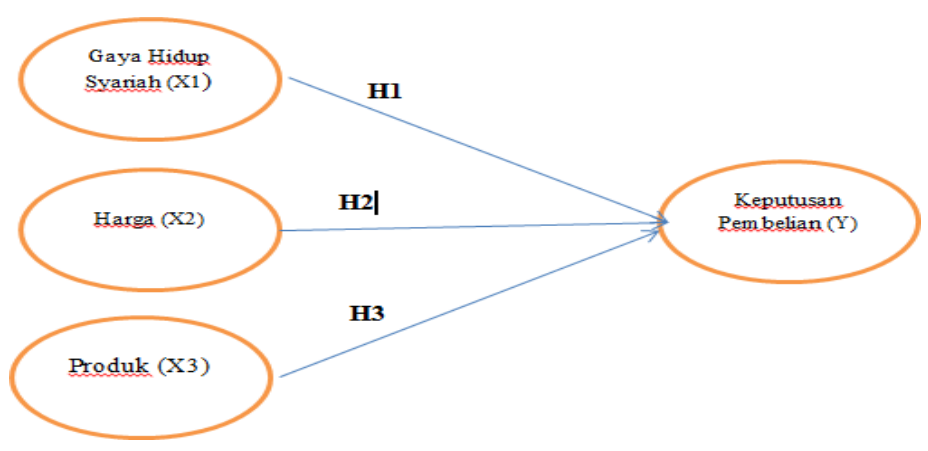

\section{Pengembangan Hipotesis}

Hipotesa merupakan simpulan dari probabilitistic sebagai jawaban atas masalah dan hipotesa juga merupakan hasil dari suatu rangkaian penalaran berbasis kerangka tertentu.

\section{Pengaruh Gaya Hidup Syariah terhadap Pengambilan Keputusan Konsumen dalam membeli produk busana muslimah}

Gaya hidup secara luas diindentifikasikan sebagai cara hidup dari setiap individu yang cenderung bagaimana seseorang tersebut menghabiskan waktu mereka (aktivitas) apa yang mereka anggap penting dalam lingkungannya (ketertarikan) apa yang mereka pikirkan tentang diri 
mereka sendiri dan dunia disekitarnya (pendapat).

Kartin dkk (2016) dengan penelitian berjudul "Pengaruh Promosi terhadap Keputusan Pembelian di Restoran Javana Bistro bandung”. Merujuk pada Agustini (2011:127), bahwa promosi merupakan suatu bentuk komunikasi pemasaran. Komunikasi pemasaran adalah aktivitas pemasaran yang berusaha untuk menyebarkan informasi, mempengaruhi atau membujuk, dan mengingatkan pasar sasaran atas perusahaan dan produknya agar bersedai menerima, membeli, dan loyal pada produk yang ditawarkan perusahaan yang bersangkutan

Dari pengembangan hipotesis tersebut maka hipotesa diajukan sebagai berikut.

H1 : Pengaruh Gaya Hidup Syariah terhadap Pengambilan Keputusan Konsumen dalam membeli produk busana muslimah

\section{Pengaruh Harga terhadap Pengambilan Keputusan Konsumen dalam membeli produk busana muslimah}

Pengertian harga menurut Michael J. Etzel adalah nilai yang disebutkan dalam mata uang atau medium moneter lainnya sebagai alat tukar namun didalam ilmu ekonomi pengertian harga mempunyai hubungan dengan pengertian nilai dan kegunaan. Nilai adalah ukuran jumlah yang diberikan oleh suatu produk apabila produk itu ditukarkan dengan produk lain. Sedangkan kegunaan adalah atribut dari sebuah item yang memberikan tingkat kepuasan tertentu padakonsumen

Intan Lina Kartin, H.p Diyah Setyorini, Masharyono (2016) dengan penelitian berjudul “Pengaruh Promosi terhadap Keputusan Pembelian di Restoran Javana Bistro bandung”. Merujuk pada Agustini (2011 :127), bahwa promosi merupakan suatu bentuk komunikasi pemasaran. Komunikasi pemasaran adalah aktivitas pemasaran yang berusaha untuk menyebarkan informasi, mempengaruhi atau membujuk, dan mengingatkan pasar sasaran atas perusahaan dan produknya agar bersedai menerima, membeli, dan loyal pada produk yang ditawarkan perusahaan yang bersangkutan

Dari pengembangan hipotesis tersebut maka hipotesa diajukan sebagai berikut:

H2 :Pengaruh Harga terhadap Pengambilan Keputusan Konsumen dalam membeli produk busana muslimah

\section{Pengaruh Produk terhadap Pengambilan Keputusan Konsumen dalam membeli produk busana muslimah}

Menurut Hermawan Kertajaya, produk adalah segala sesuatu yang dapat ditawarkan kepada pasar untuk mendapatkan perharian dimilik digunakan atau di konsumsi yang meliputi barang secara fisik, jasa, kepribadian, tempat, organisasi dan gagasan atau sebuah pikiran. Sedangkan menurut Viethzal Rivai produk adalah sesuatu yang dapat ditawarkan untuk 
memuaskan suatu kebutuhan dan keinginan. Pelanggan memuaskan kebutuhan dan keinginannya lewat produk. Istilah lain dari produk adalah penawaran atau pemecahan.

Lucano Giovani Lokman, Devi Kristanto, Monika Kristanti (2014) yang melakukan penelitian tentang "Analisis Pengaruh Kualitas Produk, Promosi, dan Interior terhadap Keputusan Pembelian Konsumen di Restoran Imperial Lalmian Tunjungan Plaza Surabaya”. Hal ini menunjukkan bahwa dengan adanya 54 promosi, konsumen yang awalanya tidak tahu akan keberadaan produk tersebut akan mengetahui, kemudian tertarik dengan promosi yang ditawarkan hingga akhirnya mengacu pada keputusan pembelian konsumen.

Dari pengembangan hipotesis tersebut maka hipotesa diajukan sebagai berikut.

H3 : Pengaruh Produk terhadap Pengambilan Keputusan Konsumen dalam membeli produk busana muslimah.

\section{METODOLOGI PENELITIAN}

Penelitian ini termasuk kategori penelitian eksplanatori, yakni penelitian yang menjelaskan konsep dan masalah (fenomena) yang diteliti untuk menentukan karakteristik dan hubungan antara fenomena dengan variabel (hubungan kausal), selanjutnya menjelaskan variabelvariabel penyebab masalah yang diteliti tersebut. Penelitian ini dapat pula disebut menggunakan metode verifikatif, yaitu menjelaskan dan menguraikan hubungan antara variabel bebas (independent) dengan variabel terikat (dependent), untuk kemudian dianalisis untuk memperoleh hasil kajian yang terbaik.

\section{Populasi}

Populasi adalah wilayah generalisasi yang terdiri atas: objek/subjek yang mempunyai kualitas dan karakteristik tertentu yang ditetapkan oleh peneliti untuk dipelajari dan kemudian ditarik kesimpulannya (Sugiono, 2011). Populasi yang diambil adalah seluruh Pelanggan wanita toko busana muslimah di kota Pekanbaru

\section{Sampel}

Sampel diambil dari seluruh populasi untuk diteliti berdasarkan karakteristik yang hendak diduga. Sampel dalam Penelitian ini terdiri dari dua kelompok, yaitu sampel kelompok uji coba instrumen dan sampel kelompok sumber data Penelitian.Sampel Uji coba instrumen ditetapkan 30 orang bertujuan untuk menguji kualitas kuesioner apakah kuesioner tersebut sudah valid dan reliabel sehingga dapat digunakan dalam Penelitian. Pengujian instrumen ini dilakukan sebelum Penelitian yang sesungguhnya dilaksanakan.

Memperhatikan pernyataan diatas, karena jumlah populasi lebih dan 100 orang, maka penarikan sampel dalam penelitian ini menggunakan proportionate stratifeld random sampling (Sugiono 2011).Proportionate stratifeld random sampling adalah pengambilan sampel dari 
anggota populasi secara acak dan berstrata secara proporsional. Dengan Teknik pengambilan sampel menggunakan rumus dari Taro Yamane atau Slovin (Riduan, 2011 ) sebagai berikut:

$$
n=\frac{N}{1+N e^{2}}
$$

Keterangan:

$\mathrm{n}=$ Ukuran sampel $\mathrm{N}=$ UkuranPopulasi

$\mathrm{e}=$ Taraf signifikansi 0,10

Sampel yang di pilih peneliti sebagai sumber data yang dibutuhkan untuk penelitian ini adalah pelanggan toko muslimah tersebut yang terletak di kota Pekanbaru. Karena lokasi toko muslimah terletak di kota Pekanbaru maka peneliti tertarik untuk mengambil populasi wanita muslimah yang berada di sekitar wilayah tersebut. Berdasarkan informasi dari toko muslimah diketahui bahwa jumlah konsumen mulai dari bulan oktober - desember adalah sekitar 2.713. Maka dirumuskan :

$$
\begin{gathered}
\boldsymbol{n}=\frac{\boldsymbol{N}}{\mathbf{1 + N \boldsymbol { e } ^ { \mathbf { 2 } }}} \\
\mathrm{n}=\frac{2.713}{1+27,13}=96,44=100
\end{gathered}
$$

Jadi berdasarkan hasil perhitungan di atas, jumlah sampel dalam penelitian ini adalah 96,44 Responden. Dengan demikian responden yang di butuhkan sebesar 100 orang konsumen yang membeli produk muslimah di toko muslimah dan pengolahan data dengan menggunakan SEM Smart Pls .Dimana teknik pengolahan nya :

\section{Statistik Deskriptif}

Dalam penelitian ini statistik deskriptif digunakan sebagai teknik analisis dengan tujuan untuk menjelaskan atau memberikan informasi demografi responden penelitian (jenis kelamin, tingkat pendidikan, dan lama bekerja) serta deskripsi mengenai variabel penelitian.

Statistik deskriptif ini digunakan untuk memberikan gambaran mengenai demografi responden. Statistik deskriptif memberikan gambaran atau deskripsi suatu data yang dilihat dari rata - rata (mean), standar deviasi, varian, maksimum dan minimum, sum, range, kurtosis dan skewness (Gozali, 2011).

\section{Statistik Inferensial}

Statistik inferensial yang digunakan dalam penelitian ini mengaplikasikan metode Structural Equation Model berbasis Partial Least Square (PLS) dengan bantuan Smart PLS 2.0 M3. Pemilihan metode PLS berdasarkan pertimbangan bahwa dalam penelitian ini terdapat konstruk yang dibentuk dengan indikator refleksif dan penelitian ini juga menggunakan 
variabel moderasi.

Seperti diketahui bahwa Moderated Regression Analysis (MRA) merupakan cara umum yang digunakan didalam regresi berganda dengan memasukkan variabel ketiga yang merupakan perkalian antara dua variabel independen (eksogen) sebagai variabel moderating. Hal ini akan menimbulkan hubungan non-linear sehingga kesalahan pengukuran dari koefisien estimasi MRA jika menggunakan variabel laten menjadi tidak konsisten dan bias, dan solusi yang bisa dilakukan adalah dengan menggunakan model persamaan struktural dimana SEM dapat mengkoreksi kesalahan pengukuran ini dengan memasukkan interaksi kedalam model.

Variabel atau konstruk dengan indikator refleksif mengasumsikan bahwa kovarian diantara pengukuran model dijelaskan oleh varian yang merupakan manifestasi domain konstruknya. Arah indikatornya yaitu dari konstruk ke indikator (Latan dan Ghozali2012). PLS tidak mensyaratkan adanya asumsi distribusi tertentu untuk estimasi parameter, sehingga teknik parametrik untuk menguji atau mengevaluasi signifikasi tidak diperlukan (Chin, 1998; Chin dan Newsted, 1999 dalam Latan dan Ghozali).

\section{Evaluasi Model Pengukuran (Outer Model)}

Evaluasi model pengukuran atau outer model dilakukan untuk menilai validitas dan reliabilitas model. Outer model dengan indikator refleksif dievaluasi melalui Convergent Validity dan Discriminant Validity dari indikator pembentuk konstruk laten dan Composite Reliabity untuk blok indikatornya (Chin, 1998 dalam Latan dan Ghozali 2012).

\section{Convergent Validity}

Convergent Validity berhubungan dengan prinsip bahwa pengukur-pengukur (manifest variabel) dari suatu konstruk seharusnya berkorelasi tinggi. Uji Convergent Validity indikator refleksif dengan program SmartPLS 2.0 M3 dapat dilihat dari nilai loading factor untuk tiap indikator konstruk. Rule of thumb yang biasanya digunakan untuk menilai Convergent Validity yaitu nilai loading factor harus lebih dari 0,7 utuk penelitian yang bersifat confirmatory dan nilai loading factor 0,6-0,7 untuk penelitian yang bersifat exploratory masih dapat diterima serta nilai average variance extraced (AVE) harus lebih besar dari 0,5. Namun demikian untuk penelitian tahap awal dari pengembangan skala pengukuran, nilai loading factor 0,5-0,6 masih dianggap cukup (Chin, 1998; dalam Latan danGhozali2012).

\section{Discriminant Validity}

Discriminant Validity berhubungan dengan prinsip bahwa pengukur (manifest variabel) konstruk yang berbeda seharusnya tidak berkorelasi tinggi. Cara untuk menguji Discriminant Validity dengan indikator refleksif yaitu dengan membandingkan akar kuadrat AVE untuk tiap konstruk dengan nilai korelasi antar konstruk dalam model. Validitas Diskriminan yang baik 
ditunjukkan dari akar kuadrat AVE untuk tiap konstruk lebih besar dari korelasi antar konstruk dalam model (Fornell dan Larcker, 1981 dalam Latan dan Ghozali2012). Nilai AVE direkomendasikan harus lebih besar dari 0,5 yang mempunyai arti bahwa 50\% atau lebih variance dari indikator dapat dijelaskan.

\section{Composite Reliability}

Setelah uji validitas, pengukuran model juga dilakukan untuk menguji reliabilitas suatu konstruk. Uji reliabilitas dilakukan untuk membuktikan akurasi, konsistensi dan ketepatan instrumen dalam mengukur konstruk. Untuk mengukur reliabilitas suatu konstruk dengan indikator refleksif dilakukan dengan Composite Reliability. Rule of Thumb yang biasa digunakan untuk menilai reliabilitas konstruk yaitu nilai Composite Reliability harus lebih besar dari 0,7 untuk penilaian yang bersifat confirmatory dan nilai 0,6-0,7 masih dapatditerima untuk penelitian yang bersifat exploratory (Latan dan Ghozali2012).

\section{Evaluasi Model Struktural (Inner Model)}

Dalam menilai model struktural dengan PLS, dimulai dengan melihat nilai R- Squares untuk setiap variabel laten endogen sebagai kekuatan prediksi dari model struktural. Perubahan nilai R-Squares dapat digunakan untuk menjelaskan pengaruh variabel laten eksogen tertentu terhadap variabel laten endogen apakah mempunyai pengaruh yang substantive. Nilai R-Squares 0,75, 0,50 dan 0,25 dapat disimpulkan bahwa model kuat, moderate dan lemah. Hasil dari PLS RSquares merepresentasi jumlah variance dari konstruk yang dijelaskan oleh model (Latan dan Ghozali 2012).

\section{Pengujian Hipotesis}

Pengujian hipotesis dilakukan dengan melihat nilai signifikasi untuk mengetahui pengaruh antar variabel. Batas untuk menolak atau menerima hipotesis yang diajukan adalah $>1,67$ (significance level $=5 \%$ ) dimana jika $\mathrm{t}$ hitung $>\mathrm{t}$ tabel $[>1,67$ ( one tailed)], maka Ha diterima dan Ho ditolak, namun jika t hitung $<\mathrm{t}$ tabel $[<1,67$ ( one tailed)], maka Ho diterima dan Ha ditolak. Selain melihat nilai t tabel, untuk menolak atau menerima hipotesis juga memperhatikan positif atau negatif nilai dari koefisien jalur.

\section{HASIL DAN PEMBAHASAN}

\section{Analisis Statistik Deskriptif}

Pada pembahasan ini akan dilihat bagaimana deskripsi secara umum dari data yang digunakan dalam penelitian ini. Dalam bagian ini akan dilihat nilai maksimum dan minimum, nilai rata-rata yang akan menunjukkan kecendrungan secara umum serta nilai standart deviasi yang menjadi alat pengukur persebaran data yang digunakan dalam penelitian ini . Analisis deskriptif ini diperlukan untuk melihat kondisi dan gambaran umum dari data yang digunakan dalam penelitian. 
Gaya Hidup Syariah

Tabel 1 Deskriptif Gaya Hidup Syariah

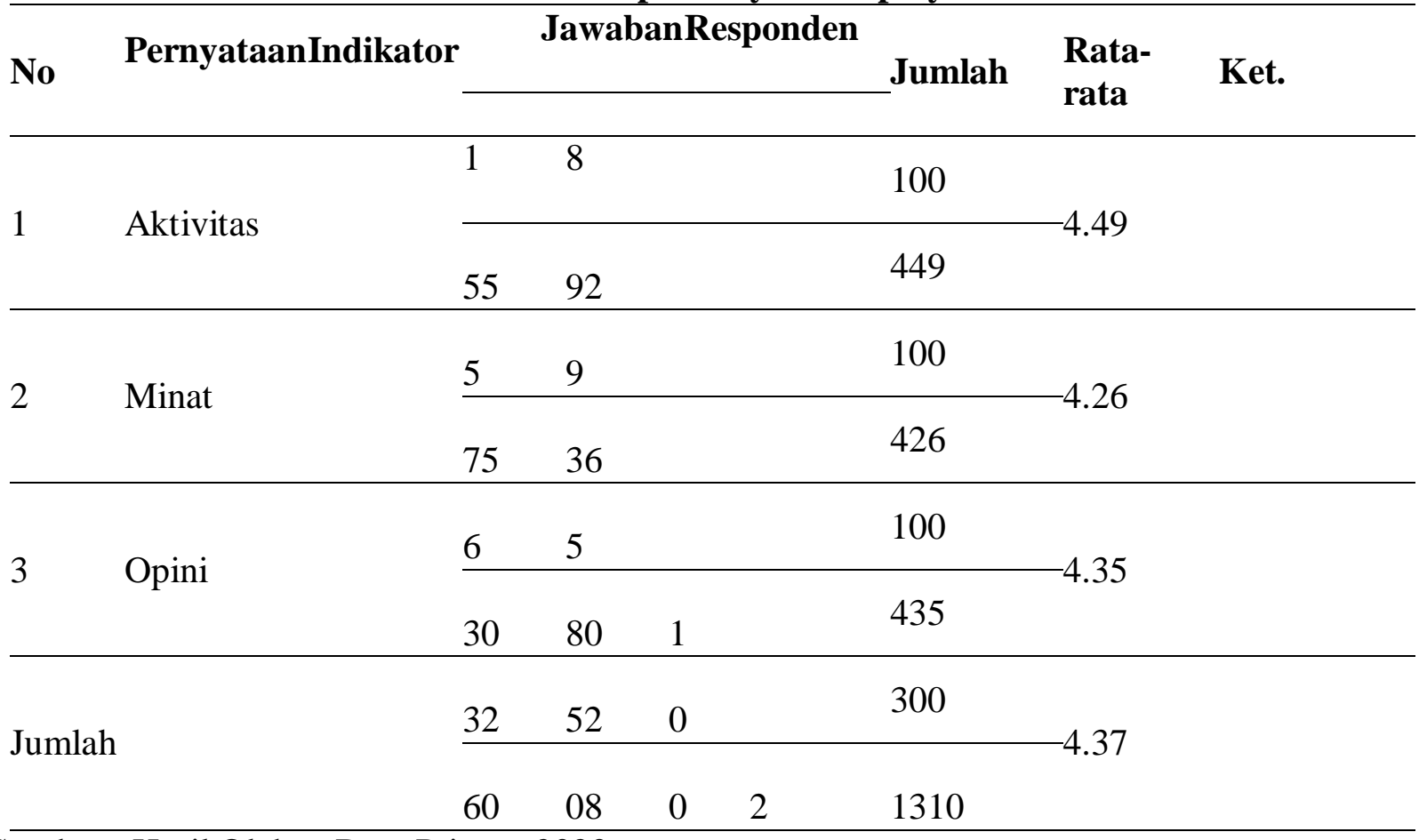

Sumber : Hasil Olahan Data Primer, 2020

Berdasarkan pada tabel 4.1 tersebut diatas maka dapat terlihat bahwa nilai dari jawaban responden terhadap variabel Gaya Hidup Syariah dengan indicator Aktivitas nilai nya 449 dengan nilai rata-rata 4,49, indkator ke dua Minat nilainya 426 dengan nilai rata-rata 4,26 . indikator ke tiga Opini nilainya 435 dengan nilai rata-rata 4,35 Artinya variabel Gaya Hidup Syariah sebaranya baik

\section{Produk}

Tabel 2 Deskriptif Produk

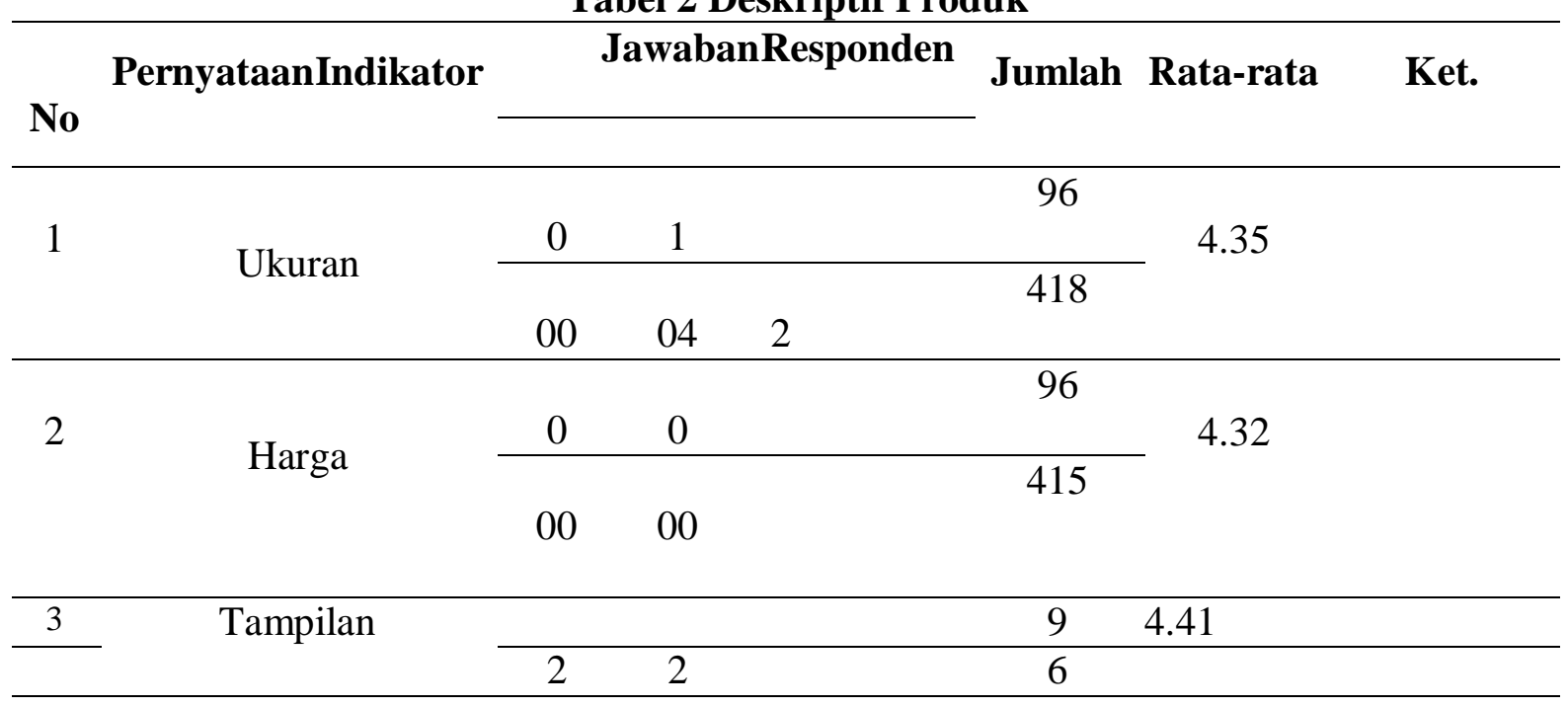




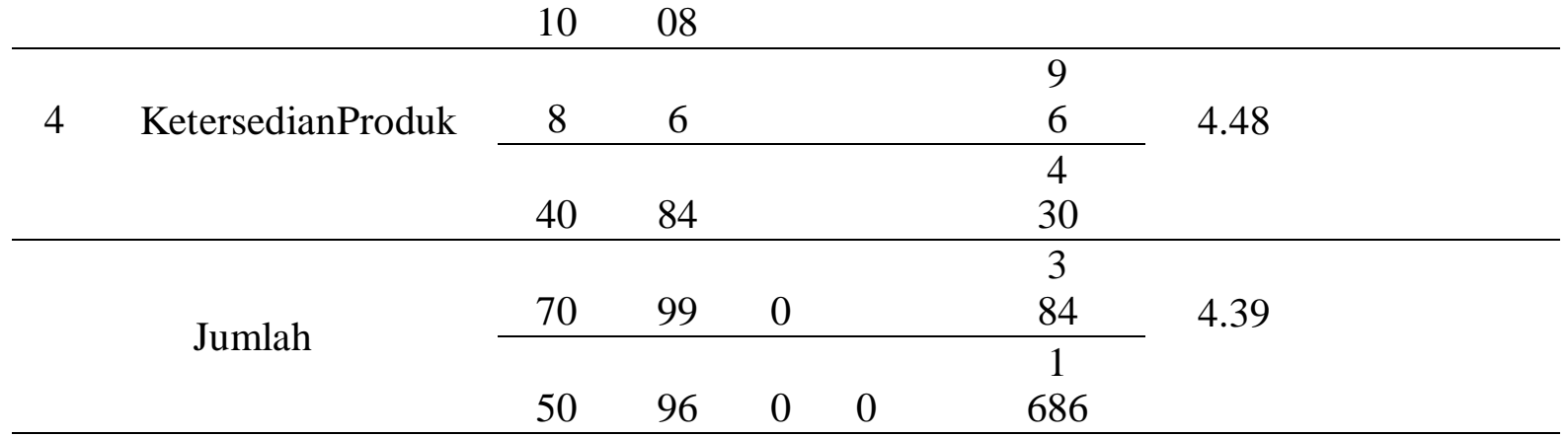

Sumber : Hasil Olahan Data Primer, 2020

Berdasarkan pada tabel 4.2 tersebut diatas maka dapat terlihat bahwa nilai dari jawaban responden terhadap variabel Produk dengan indicator Ukuran nilai nya 418 dengan nilai rata-rata 4,35 ,indkator ke dua Harga nilai 415 dengan nilai rata-rata 4,32 . indicator ke tiga Tampilan nilainya 423 dengan nilai rata-rata 4,41. Indicator ke empat Ketersediaan produk nilainya 430 dengan nilai rata-rata 4,48 Artinya variabel Produk sebaranya seragam Harga

Tabel 3 Deskriptif Harga

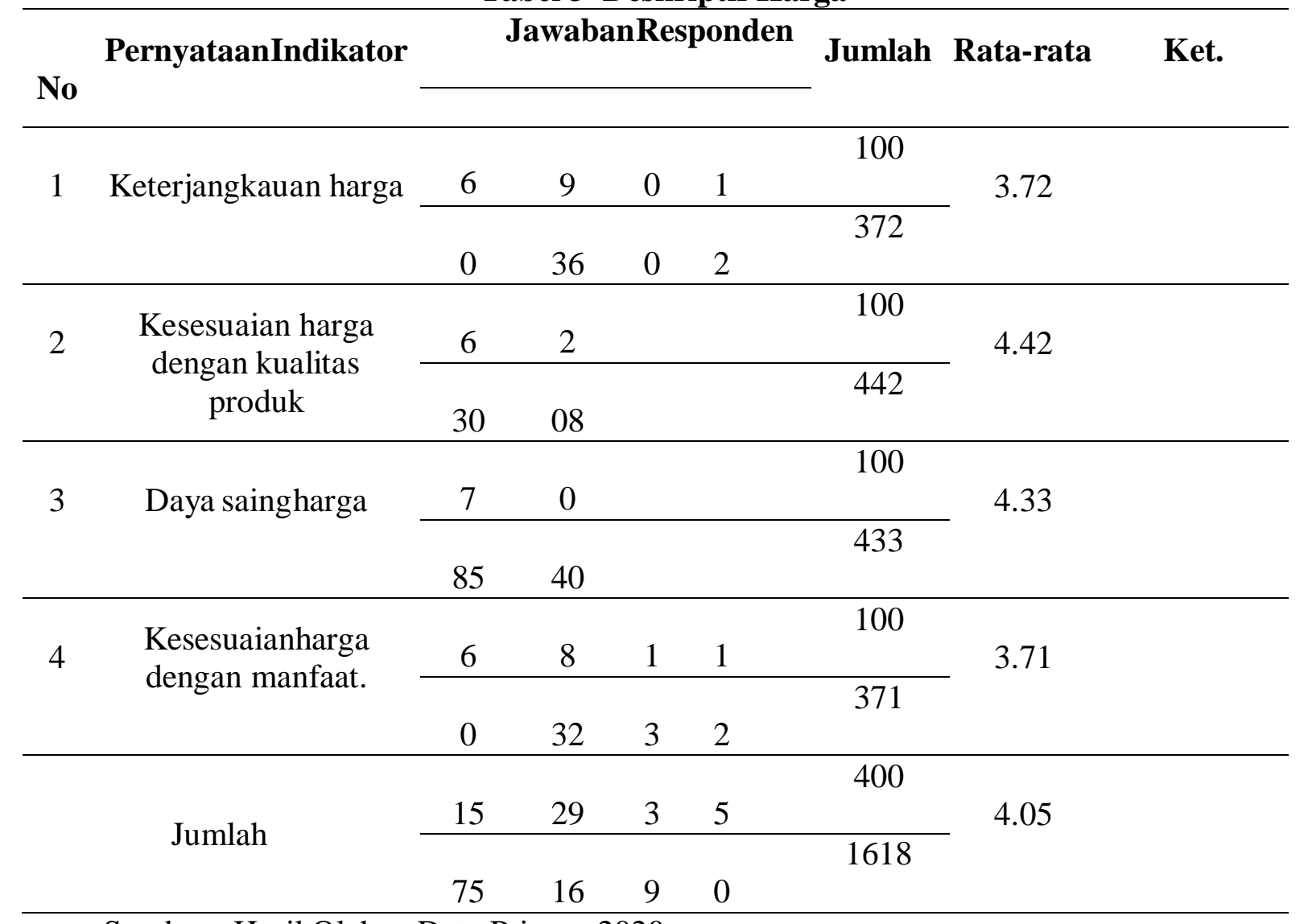

Sumber : Hasil Olahan Data Primer, 2020 
Berdasarkan pada tabel 4.3 tersebut diatas maka dapat terlihat bahwa nilai dari jawaban responden terhadap variabel Harga dengan indicator Keterjangakauan harga nilai nya 372 dengan nilai rata-rata 3,72, indkator ke dua Kesesuaian harga dengan kualitas produk 442 dengan nilai rata-rata 4,42 . indicator ke tiga Daya Saing Harga nilainya 433 dengan nilai rata-rata 4,33. Indicator ke empat Kesesuaian harga dengan manfaat nilainya 371 dengan nilai rata-rata 3,71 Artinya variabel Harga sebaranya seragam

\section{Keputusan Pembelian}

Tabel 4 Deskriptif Keputusan Pembelian

\begin{tabular}{|c|c|c|c|c|c|c|}
\hline No & $\begin{array}{l}\text { Pernyataan } \\
\text { Indikator }\end{array}$ & & JawabanResponden & Jumlah & $\begin{array}{l}\text { Rata- } \\
\text { rata }\end{array}$ & Ket. \\
\hline \multirow[t]{2}{*}{1} & \multirow[t]{2}{*}{$\begin{array}{l}\text { Kemantapan } \\
\text { sebuah produk. }\end{array}$} & & 2 & 100 & \multirow{2}{*}{-4.31} & \\
\hline & & 75 & 48 & 431 & & \\
\hline \multirow{2}{*}{2} & \multirow[t]{2}{*}{$\begin{array}{l}\text { Kebiasaan } \\
\text { dalammembeliproduk. }\end{array}$} & 6 & 9 & 100 & \multirow{2}{*}{-4.28} & \\
\hline & & 80 & 36 & 428 & & \\
\hline \multirow{2}{*}{3} & \multirow{2}{*}{$\begin{array}{l}\text { Memberikan } \\
\text { rekomendasi } \\
\text { orang lain }\end{array}$} & 8 & 9 & 100 & \multirow{2}{*}{-4.42} & \\
\hline & & 40 & 96 & 442 & & \\
\hline \multirow[t]{2}{*}{4} & \multirow[t]{2}{*}{$\begin{array}{l}\text { Melakukan pembelian } \\
\text { ulang }\end{array}$} & & 1 & 100 & \multirow{2}{*}{-4.30} & \\
\hline & & 75 & 44 & 430 & & \\
\hline \multicolumn{2}{|c|}{ Jumlah } & 54 & 31 & 400 & 4.33 & \\
\hline
\end{tabular}

Sumber : Hasil Olahan Data Primer, 2020

Berdasarkan pada tabel 4.4 tersebut diatas maka dapat terlihat bahwa nilai dari jawaban responden terhadap variabel Keputusan Pembelian dengan indicator Kemantapan pada sebuah produk nilai nya 431 dengan nilai rata-rata 4,31, indkator ke dua Kebiasaan dalam membeli produk. 428 dengan nilai rata-rata 4,28. indicator ke tiga Memberikan rekomendasi kepada orang lain nilainya 442 dengan nilai rata-rata 4,42. Indicator ke empat Melakukan pembelian ulangnilainya 430 dengan nilai rata-rata 4,30 Artinya variabel Harga sebaranya seragam.

\section{Analisis Partial Least Square (PLS)}


Dalam penelitian ini analisis data menggunakan pendekatan Partial Least Square (PLS) yang menggunakan software smartPLS 3.0 M3. Partial Least Square (PLS) adalah model persamaan struktural (SEM) yang berbasis komponen variance. Pendekatan PLS adalah distribution free (tidak menggunakan data berdistribusi tertentu, dapat berupa nominal, kategori, ordinal, interval maupun rasio). Selain itu PLS juga dapat digunakan untuk mengukur sampel yang jumlahnya kecil. Berikut ini tahap-tahap menggunakan pendekatan Least Square (PLS) dengan menggunakan software smartPLS.

\section{Menilai Outer Model atau Measurement Model}

Terdapat tiga kriteria di dalam penggunaan teknik analisis data dengan SmartPLS untuk menilai outer model yaitu Convergent Validity, Discriminant Validity dan Composite Reliability. Berikut adalah gambar PLS Algorithm pada penelitian ini.

\section{Outer Model}

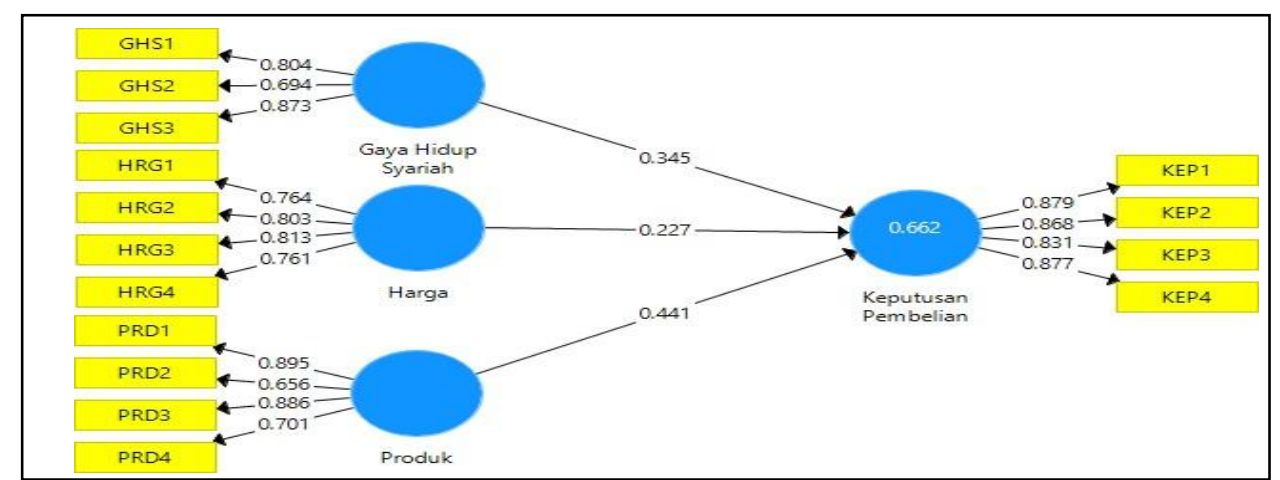

Sumber : Hasil Olahan Data Primer, 2020

Kiretria-kriteria pada PLS Algorithm dapat dijelaskan pada uraian dibawah ini.

Cronbach's AlphaComposite Reliability dan

Average Variance Extracted (AVE)

\begin{tabular}{llll}
\hline Variabel & $\begin{array}{l}\text { Cronbach's } \\
\text { Alpha }\end{array}$ & $\begin{array}{l}\text { Composite } \\
\text { Reliability }\end{array}$ & $\begin{array}{l}\text { AverageVariance } \\
\text { Extracted (AVE) }\end{array}$ \\
\hline Gaya HidupSyariah & 0.708 & $\begin{array}{l}0.83 \\
5\end{array}$ & 0.630 \\
\hline Harga & 0.812 & $\begin{array}{l}0.86 \\
5\end{array}$ & 0.617 \\
\hline KeputusanPembelian & 0.888 & $\begin{array}{l}0.92 \\
2\end{array}$ & 0.746 \\
\hline Produk & 0.801 & $\begin{array}{l}0.86 \\
8\end{array}$ & 0.627 \\
\hline
\end{tabular}

Sumber : Olahan Data SmartPLS, 2020 
Berdasarkan tabel 4.5. dapat disimpulkan bahwa semua konstruk memenuhi kriteria reliabel. Hal ini ditunjukkan dengan nilai Cronbach's Alpha composite reliability di atas 0,70 dan AVE diatas 0,50 sebagaimana kriteria yang direkomendasikan.

\section{Pengujian Signifikansi dan Pengujian Hipotesis}

Dalam PLS pengujian secara statistik setiap hubungan yang dihipotesiskan dilakukan dengan menggunakan simulasi. Dalam hal ini dilakukan metode bootstrap terhadap sampel.

\section{bootstrap}

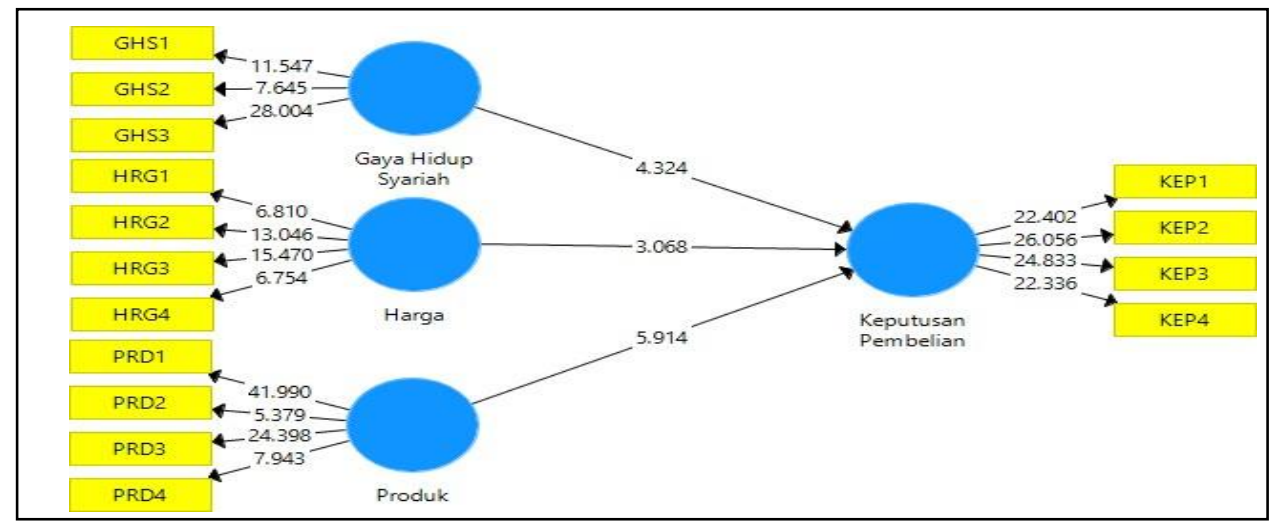

Sumber : Hasil Olahan Data Primer, 2020

Berdasarkan gambar di atas berikut akan dijelaskan pengujian masing-masing hipotesis.

\section{Pegujian Hipotesis}

Model struktural (inner model) merupkan model struktural untuk memprediksi hubungan kausalitas antar variabel laten (Gozali, 2012:77). Untuk memprediksi adanya hubungan kauslitas dalam SEM-PLS dengan menggunakan SmartPLS 3.0 M3 sebagai berikut

\section{Result For Inner Weights}

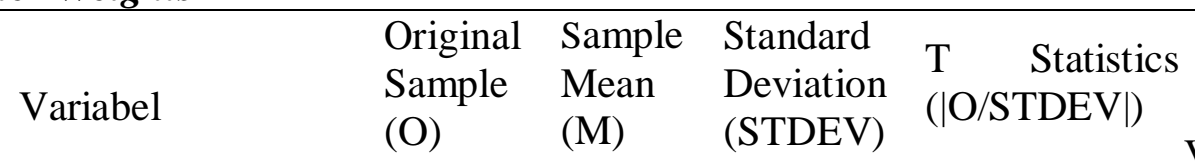

\begin{tabular}{lccccc}
\hline $\begin{array}{l}\text { Gaya Hidup Syariah -> Keputusan } \\
\text { Pembelian }\end{array}$ & 0.345 & 0.344 & 0.080 & 4.324 & .000 \\
\hline Jarga -> KeputusanPembelian & 0.227 & 0.234 & 0.074 & 3.068 & .002 \\
\hline roduk -> KeputusanPembelian & 0.441 & 0.439 & 0.075 & 5.914 & .000 \\
\hline
\end{tabular}

Sumber : Olahan Data SmartPLS, 2020 
Berdasarkan hasil analisis yang dapat dilihat pada tabel diatas menunjukan nilai koefisien Gaya Hidup Syariah terhadap Keputusan Pembelian sebesar 0,345 dengan nilai t hitung sebesar 4.324. Nilai tersebut lebih besar dari t tabel 1.985. Hasil ini membuktikan pengaruh signifikanGaya Hidup Syariah terhadap Keputusan Pembelian.

Berdasarkan hasil analisis yang dapat dilihat pada tabel diatas menunjukan nilai koefisien harga terhadap Keputusan Pembelian sebesar 0,227 dengan nilai t hitung sebesar 3,068. Nilai tersebut lebih besar dari t tabel 1.985. Hasil ini membuktikan pengaruh signifikanharga terhadap Keputusan Pembelian.

Berdasarkan hasil analisis yang dapat dilihat pada tabel diatas menunjukan nilai koefisien produk terhadap Keputusan Pembelian sebesar 0,441 dengan nilai t hitung sebesar 5,914. Nilai tersebut lebih besar dari t tabel 1.985. Hasil ini membuktikan pengaruh signifikanproduk terhadap Keputusan Pembelian

\section{KESIMPULAN}

Berdasarkanhasilpenelitianinitelahmenunjukkanbahwa Gaya Hidup Islami, Produk, Harga Terhadap Keputusan Pembelian produk Busana Muslimah di Kota Pekanbaru Untuklebihjelasnyapenelititelahmemberikanketeranganmengenaihasil kesimpulan penelitian inisebagai berikut

1. Gaya Hidup Syariah berpengaruh positif dan signifikan terhadap Keputusan Pembelian menunjukan nilai koefisien jalursebesar 0,345 dengan nilai t hitung sebesar 4.324. Nilai tersebut lebih besar dari t tabel 1.985. Hasil ini membuktikan pengaruh signifikanGaya Hidup Syariah terhadap Keputusan Pembelian

2. Harga Berpengaruh positif dan signifikan terhadap keputusan pembelianmenunjukan nilai koefisien jalursebesar0,227 dengan nilai t hitung sebesar 3,068. Nilai tersebut lebih besar dari $t$ tabel 1.985. Hasil ini membuktikan pengaruh signifikan Harga terhadap Keputusan Pembelian

3. Produk Berpengaruh positif dan signifikan terhadap keputusan pembelianmenunjukan nilai koefisien jalursebesarsebesar 0,441 dengan nilai t hitung sebesar 5,914. Nilai tersebut lebih besar dari t tabel 1.985.Hasil ini membuktikan pengaruh signifikan Produk terhadap Keputusan Pembelian

\section{Saran}

Untuk penelitian selanjutnya ,ada beberapa saran yang dapat di pertimbangkan agar penelitian mendatang menjadi lebih baik . Variabel yang digunakan untuk penelitian ini 
sedikit, yaitu hanya 3 variabel, oleh sebab itu pada penelitian selanjutnya dapat menambah variabel lainnya yang berhubungan dengan keputusan pembelian. Sehingga dapat memberikan gambaran yang lebih luas mengenai pengambilan keputusan konsumen dalam membeli produk busana muslimah

\section{DAFTAR PUSTAKA}

Abdul Ghafur,’Perbankan Syariah diIndonesiaYogyakarta: Gajah Mada University,2007

Adnan, Shobih "UU JPH dan masa depan produk halal diIndonesia", Pada Metrotvnews :http://news.metrotvnews.com/news/ybJy99WN-uu-jph-dan-masadepan-produk- halalindonesia. Diakses pada 7 maret 2018.

Anwar Hidayat, "Penjelasan Berbagai Jenis Uji Validitas dan Cara Hitung”(www.statistikan.com, diakses pada21 maret 2018). 2010

Arikunto, "Prosedur Penelitian dari Suatu Pendekatan Praktik", Jakarta: Rineka Cipta,

Asep Hermawan, "Penelitian Bisnis MetodeKuantitatif", (Jakarta: PT. Grasindo,2005).

Ashad, Teori Moderinasdan Globalisasi, Sidoarjo : Kreasi Wacana, 2012. Dewi,Leli. "Labanancantik dari bisnis spa", jogjakarta: KDT 2011.

Dicky Hamda, "Pengaruh Gaya Hidup dan Harga Terhadap Keputusan Pembelian Blackberry" padaHttp://Elib.Unikom.Ac.Id/Files/Disk1/716/Jbptunikompp-Gdl-Dickyhamda35771-5-Unikom D-I.Pdf.DiaksesPada:6Februari2018 Pk1 02.00.

Dwi,Murjiati, jurnal "Hubungan Harga dan Produk dengan Keputusan Pembelian Produk fashion dalam Berbelanja secara Online” pada file:///C:/Users/USER/Downloads/Documents/T1_162007037_BAB\%20II.pdf.

Fernan Rahadi, "gaya hidup syariah pada kelas menengah muslim"Koran sindo pada :https://nasional.sindonews.com/read/1036032/162/percaya-diri-dengan-gaya-hidup-syariah1440300196.

Ghozali, Imam. 2012. Aplikasi Structural equation modeling: Metode alternatif dengan partial least square ( $p l s$ ) Semarang: Badan Penerbit - Universitas Diponegoro.

Istijanto,“Aplikasi Praktis Riset Pemasaran”,Jakarta: Gramedia Pustaka Utama, 2009.

JefryBunjanto, Jurnal "Pengaruh Periklanan, Citra Merek, Norma Subjektif, Labelilisasi Halal, Brand Ambassador Dan Persepsi Harga TerhadapKeputusan

Pembelian”,(Jogjakarta:Um Jogja 2015).

Kuncoro, Mudrajat. "Metode Riset Untuk Bisnis \& Ekonomi, Bagaimana Meneliti Dan Menulis Tesis", Jakarta: Erlangga, 2003. 
Kurniawati Hasanah, Jurnal "Hijabers Community, Gaya Hidup Sebagai Moderasi Dan Keputusan Pembelian Di Galery Elzatta Madiun", (Madiun:Manajemen Stie Dharma Iswara,2012).

Kotler, Philip dan Amstrong, Gary, (2014), Principles of Marketin, 12th Edition, Jilid 1 Terjemahan Bob Sabran Jakarta : Erlangga

Lambat supiyoadi, manajemen pemasaran edisi3, Jakarta, 2012, salemba empat.

Laras Adhianti. "Pengaruh Gaya Hidup, Citra Merek, dan Atribut Produk Terhadap Keputusan Pembelian Hijab Zoya Di Jakarta Selatan”,(Jakarta:Universitas Syarif Hidayatullah, 2017).

Leonardi Gunawan, "strategi took kelontong kalahkan minimarket" dalamartikel (https://www.kompasiana.com/ha-eun/strategi-marketing-minimarket-kalahkantokokelontong_55d982476e7a614607cee726diaksespada 02 februari 2018.

Masyhuri dan Zainuddin, "Metodelogi Penelitian Pendekatan Praktis Dan Aplikatif", Bandung:Refika Aditama, 2011

Nasrullah Muhammad, "Islamic branding, religiusitas dan keputusan konsumen dalam memilih produk" jurnal Hukum Islam(JHI) : http://e-journal.stainpekalongan.ac.id/index.php/jhidiakses pada7 maret 2018

Marius Angipora, Dasar-dasar Pemasaran , Raja Grafindo, Jakarta, 2002

Sugiyono. 2011. Metode Penelitian Kuantitatif, Kualitatif dan R\&D. Bandung: Afabeta

Ulfa, Rizkiyana. Skripsi " Pengaruh Hijabers Community Terhadap Gaya Hidup Dan Keputusan Pembelian Hijab Pada Mahasiswa Fakultas Ekonomi Universitas Jember", (Jember: Universitas Jember, 2017) 